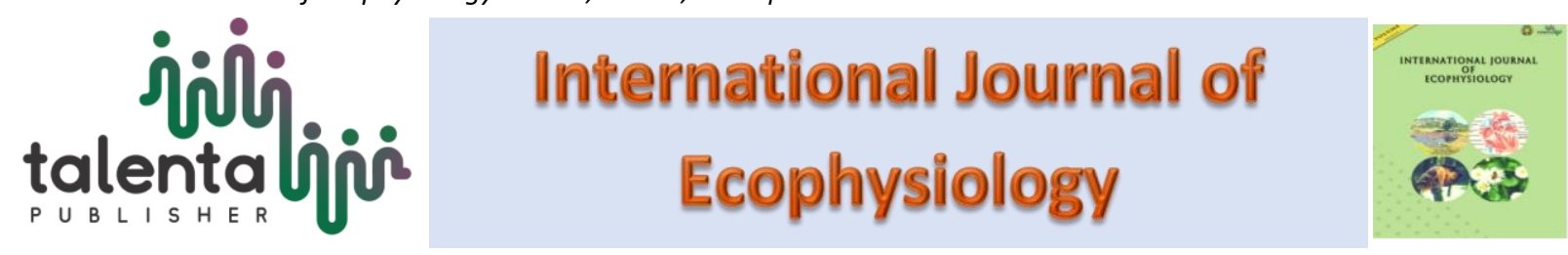

\title{
Analysis of Concentration of Heavy Metal (Pb) and Cadmium (Cd) In Waterfish (Eichhornia crassipes) in Indragiri River, Riau
}

\author{
Elya Febrita ${ }^{1}$,Suwondo ${ }^{1}$,Dimas Bayu Hidayat ${ }^{1}$ \\ Biology Education Study Program, Faculty of Teacher Training and Education, Universitas Riau, , \\ Pekanbaru, Indonesia
}

\begin{abstract}
Research has been conducted to determine the concentration of Lead $(\mathrm{Pb})$ and Cadmium (Cd) heavy metals in water hyacinth (Eichhornia crassipes) in the Indragiri River Waters of Indragiri Hilir Regency in May-July 2016. Determination of the research station was carried out by purposive random sampling by considering environmental conditions based on community activities around the river and the existence of Eichhornia crassipes. The main parameters in this study include the concentration of heavy metals $\mathrm{Pb}$ and $\mathrm{Cd}$ in river water, sediments and Eichhornia crassipes, and physico-chemical parameters as supporting parameters. The results showed that the average concentration of $\mathrm{Pb}$ heavy metals in river water was $0.276 \mathrm{ppm}$ and $\mathrm{Cd}$ was $0.126 \mathrm{ppm}$. The average concentration of heavy metals $\mathrm{Pb}$ in sediments was $4.61 \mathrm{ppm}$ and $\mathrm{Cd}$ of $0.75 \mathrm{ppm}$. The accumulation of $\mathrm{Pb}$ and $\mathrm{Cd}$ Eichhornia crassipest heavy metals is included in the low category, namely the average concentration of $\mathrm{Pb}$ heavy metals in the root organ is $3.02 \mathrm{ppm}$, on the leaf stalk $2.61 \mathrm{ppm}$, and on the leaves $2.09 \mathrm{ppm}$. The concentration of heavy metal $\mathrm{Cd}$ at the root was $0.47 \mathrm{ppm}$, at the leaf stalk $0.39 \mathrm{ppm}$, and at the leaves $0.362 \mathrm{ppm}$.
\end{abstract}

Keyword: Eichhornia crassipes, $\mathrm{Pb}$ and $\mathrm{Cd}$ heavy metals, water pollution

Received 1 November 2019 | Revised 20 December2019 | Accepted 26 January2020

\section{Introduction}

The river is one of the water resources that is very important for human life. However, along with the development of various human activities along river waters, it can increase the risk of water quality degradation. The decline in water quality is caused by the entry of waste disposal, which causes changes in the physical, chemical, biological and aesthetic quality of the waters. This has an impact on the function of waters that are no longer suitable for their purpose in supporting most of the life of aquatic organisms and human needs. Among the dangerous pollutants that can change the quality and damage the carrying capacity of the aquatic

\footnotetext{
*Corresponding author at: Biology Education Study Program, Faculty of Teacher Training and Education, Universita Riau, Pekanbaru, Indonesia 
environment are heavy metals.The Indragiri River is the largest river in the Indragiri Hilir Regency region, which originates from Lake Singkarak and empties into the Berhala Strait [1]. Indragiri River has a very important function, namely as a means of catching and fish farming, agricultural irrigation, and MCK activities (bathing, washing, toilet). The Indragiri River in the Indragiri Hilir Regency is included in the downstream part of the river and has the potential to receive heavy metal waste originating from activities along the river waters such as domestic activities, gold mining, sand and gravel, the coconut and palm oil processing industry, ports, pathways ship transportation traffic both passenger ships and cargo ships. With this activity, it is possible for pollution by heavy metals, including Lead $(\mathrm{Pb})$ and Cadmium $(\mathrm{Cd})$ heavy metals.

Heavy metals $\mathrm{Pb}$ and $\mathrm{Cd}$ are heavy metals that are highly toxic to human health. Based on the results of research conducted by Nola Oktaria [2], the concentration of $\mathrm{Pb}$ and $\mathrm{Cd}$ heavy metals in the waters of the Indragiri River has exceeded the established quality standards. The concentration of heavy metals $\mathrm{Pb}$ in the Indragiri River water is $0.99 \mathrm{ppm}$, while the concentration of heavy metals $\mathrm{Cd}$ in the Indragiri River water is $0.17 \mathrm{ppm}$. According to PP No. 82 of 2001 concerning Management of Water Quality and Water Pollution Control, the permissible concentration of $\mathrm{Pb}$ heavy metals for river waters is $0.03 \mathrm{ppm}$ and the permissible concentration of heavy metals $\mathrm{Cd}$ is $0.01 \mathrm{ppm}$. One alternative to evaluating the quality of river waters is to do biomonitoring. Biomonitoring is an environmental evaluation technique using living organisms, by observing levels of pollutants contained in the organism's body tissue to a more specific effect. This method can be used to measure the level of contamination or the level of heavy metal pollution in aquatic ecosystems [3]. The biomonitoring process requires indicator organisms (bioindicators) to determine the level of heavy metal contamination. One type of aquatic plants that can be used as biomonitoring for heavy metal pollution is water hyacinth (Eichhornia crassipes). Eichhornia crassipes is a type of aquatic plant that has a high tolerance to be able to grow well in areas polluted by waste and able to absorb pollutants such as heavy metals $\mathrm{Pb}$ and $\mathrm{Cd}$ and then accumulate heavy metals in their body tissues. Eichhornia crassipes has the ability as a bioaccumulator that can absorb cations or heavy metal anions contained in wastewater and can grow fast enough and survive in bad conditions [4].

\section{Materials and Methods}

This research is an exploratory study through the results of examinations or test samples in the laboratory. The research was conducted at the Laboratory of Chemical Testing and Analysis, Faculty of Engineering, University of Riau in May-July 2016. Samples from the study were river water, sediments, root organs, petioles, and leaves of Eichhornia crassipes. The station was determined by purposive random sampling technique so that 5 research stations were obtained. Samples taken from the five stations are put into a sterile container to be brought to the laboratory. The initial step is to do the sample destruction process and then check the concentration of heavy metals using AAS (Atomic Absorption Spectrophotometer). The data 
obtained were analyzed descriptively, where the data obtained were presented in the form of dangrafik tables, then compared with the custom values

\section{Result and Discussion}

\subsection{Lead Heavy Metal $(\mathrm{Pb})$ and Cadmium $(\mathrm{Cd})$ Concentration in River Water and Sediment}

The results of measurements of $\mathrm{Pb}$ and $\mathrm{Cd}$ heavy metal concentrations in river water and sediment at each Indragiri River waters research station Indragiri Hilir Regency can be seen in Table 1 .

Table 1. Results of Measurement of $\mathrm{Pb}$ and Cd Heavy Metal Concentrations detected in River Water and Sediments in the Indragiri River Waters of Indragiri Hilir Regency

\begin{tabular}{ccccc}
\hline \multirow{2}{*}{ Station } & \multicolumn{2}{c}{ River water $(\mathrm{ppm})$} & \multicolumn{2}{c}{ Sediment $(\mathrm{ppm})$} \\
\cline { 2 - 5 } & $\mathrm{Pb}$ & $\mathrm{Cd}$ & $\mathrm{Pb}$ & $\mathrm{Cd}$ \\
\hline I & 0.19 & 0.08 & 4.60 & 0.66 \\
II & 0.27 & 0.10 & 4.69 & 0.80 \\
III & 0.11 & 0.06 & 3.96 & 0.50 \\
IV & 0.36 & 0.18 & 4.81 & 0.84 \\
V & 0.45 & 0.21 & 4.97 & 0.92 \\
\hline Quality standards & $0.003^{*}$ & $0.001^{*}$ & $47.82-161.06^{* *}$ & $0.65-2.49^{* *}$ \\
\hline
\end{tabular}

Note*: Quality standard of heavy metals in river water (PP No. 82 of 2001 concerning water quality management and water pollution control). **: Quality standards for heavy metals in sediments (USEPA, 2004)

From Table 1 shows that the concentrations of heavy metals $\mathrm{Pb}$ and $\mathrm{Cd}$ at each Indragiri River waters research station in Indragiri Hilir Regency have different concentrations. $\mathrm{Pb}$ heavy metal concentrations in river water ranged from $0.11 \mathrm{ppm}$ to $0.45 \mathrm{ppm}$ and $\mathrm{Pb}$ heavy metal concentrations in sediments ranged from $3.96 \mathrm{ppm}$ to $4.97 \mathrm{ppm}$. While the concentration of heavy metal $\mathrm{Cd}$ in river water ranges from $0.06 \mathrm{ppm}$ to $0.21 \mathrm{ppm}$ and the concentration of heavy metal $\mathrm{Cd}$ in sediments ranges from $0.50 \mathrm{ppm}$ to $0.92 \mathrm{ppm}$. This proves that the $\mathrm{Pb}$ heavy metal concentration is higher than the Cd heavy metal concentration, presumably because the use of $\mathrm{Pb}$ heavy metal in activities around the research station is more than the use of Cd heavy metal.

The concentration of heavy metals $\mathrm{Pb}$ and $\mathrm{Cd}$ on the sediment tends to be higher than in river water. This shows that there is accumulation of heavy metals in the sediments resulting in a buildup in the bottom of the water. Whereas in river water, heavy metals $\mathrm{Pb}$ and $\mathrm{Cd}$ undergo continuous dilution processes in accordance with the increase in water mass and the current pattern that spreads the heavy metals to other places.

The highest concentrations of heavy metals $\mathrm{Pb}$ and $\mathrm{Cd}$ in river water and sediment were found at Station $\mathrm{V}$. The high concentration of heavy metals $\mathrm{Pb}$ and $\mathrm{Cd}$ was due to Station $\mathrm{V}$ including the downstream river which has the potential to receive heavy metal waste originating from activities along the river waters. In addition, Station V is a densely populated area and is close to a port that allows high levels of heavy metal waste from $\mathrm{Pb}$ and $\mathrm{Cd}$. 
Port and transportation activities can contribute to the entry of $\mathrm{Pb}$ heavy metal pollution into river waters. Pollution comes from oil dumps, shipyard irons and pipes that have undergone corrosion, batteries or batteries, ballast water discharges, and engine fuel oil emissions. Darrmono [5] states that $\mathrm{Pb}$ heavy metals can enter water bodies through the disposal of ballast water and oil-fuel emissions which are used as anti-knocking addictive substances in the engine. The heavy metal $\mathrm{Pb}$ contained in the fuel oil is then released into the atmosphere through a smoke removal device and then dissolved in water. Cd heavy metal concentrations at Station $\mathrm{V}$ are higher when compared to other stations due to corroded pipes and domestic waste disposal such as used cans, plastic waste, batteries, and lubricating oil. This is in accordance with the opinion of Safitri, et al. [6] which states that the source of heavy metal Cd comes from oil and domestic waste such as battery waste and lubricating oil. The lowest concentrations of heavy metals $\mathrm{Pb}$ and $\mathrm{Cd}$ in river water and sediment were found at Station III. The low concentration of heavy metals $\mathrm{Pb}$ and $\mathrm{Cd}$ at this station compared to other stations is because Station III is an area far from residential areas and there is no industrial activity so that the contribution of heavy metal entry is smaller than at other stations. Low concentrations of heavy metals $\mathrm{Pb}$ and $\mathrm{Cd}$ in river water and sediment at Station III are also associated with higher $\mathrm{pH}$ compared to other stations and low temperatures (Table 3).

Based on the quality standard determined in PP No.82 of 2001 concerning Water Quality Management and Water Pollution Control, it is known that the concentration of heavy metals $\mathrm{Pb}$ and $\mathrm{Cd}$ for river water in the waters of the Indragiri River Indragiri Hilir Regency has exceeded the specified quality standard. Based on the quality standard of the range of natural heavy metals in sediments according to USEPA [7], it is known that the concentration of heavy metals $\mathrm{Pb}$ and $\mathrm{Cd}$ in the sediments of the Indragiri River waters of Indragiri Hilir Regency has not exceeded the specified quality standard values.

\subsection{Lead Metal $(\mathrm{Pb})$ and Cadmium $(\mathrm{Cd})$ concentrations in Eichhornia crassipes}

The results of measurements of heavy metal concentrations of $\mathrm{Pb}$ and $\mathrm{Cd}$ on Eichhornia crassipes are presented in Table 2.

Tabel 2. Results of Measurement of $\mathrm{Pb}$ and $\mathrm{Cd}$ Heavy Metal Concentrations in Eichhornia crassipes in the Indragiri River Waters of Indragiri Hilir Regency .

\begin{tabular}{ccccccc}
\hline \multirow{2}{*}{ Station } & \multicolumn{2}{c}{ Metal Concentration of Pb $(\mathrm{ppm})$} & \multicolumn{3}{c}{ Metal Concentration of Cd (ppm) } \\
\cline { 2 - 7 } & Root & Petiole & Leaf & Root & Petiole & Petiole \\
\hline I & 2.43 & 2.17 & 1.79 & 0.34 & 0.30 & 0.29 \\
II & 2.78 & 2.44 & 2.09 & 0.46 & 0.38 & 0.35 \\
III & 2.20 & 1.67 & 0.51 & 0.29 & 0.24 & 0.23 \\
IV & 3.31 & 2.76 & 2.61 & 0.49 & 0.42 & 0.37 \\
V & 4.37 & 4.00 & 3.44 & 0.74 & 0.62 & 0.57 \\
\hline
\end{tabular}

From Table 2 shows that the results of measurements of the heavy metal concentrations of $\mathrm{Pb}$ and $\mathrm{Cd}$ in Eichhornia crassipes organs at each station are different. $\mathrm{Pb}$ heavy 
metal concentrations in root organs ranged from 2.20 to $4.37 \mathrm{ppm}$, in leaf organ organs ranged from 1.67 to $4.00 \mathrm{ppm}$, and in leaf organs ranged from 0.51 to $3.44 \mathrm{ppm}$. While the concentration of heavy metal $\mathrm{Cd}$ in the root organ ranged from 0.29 to $0.74 \mathrm{ppm}$, in the leaf stalk organ ranged from 0.24 to $0.62 \mathrm{ppm}$, and in the leaf organ ranged from 0.23 to $0.59 \mathrm{ppm}$.

The highest $\mathrm{Pb}$ and $\mathrm{Cd}$ heavy metal concentrations are at Station $\mathrm{V}$ and the lowest is at Station III. The high and low concentrations of heavy metals at Eichhornia crassipes are highly dependent on the amount of heavy metal pollutant input into the waters. This is due to differences in the concentration of heavy metals $\mathrm{Pb}$ and $\mathrm{Cd}$ between the two types of media, namely media in plant tissue and water and sediment media as their place of life. Thus, the accumulation of heavy metals in the body of the organism depends on the concentration of heavy metals in water and sediments.

The process of absorption and accumulation of heavy metals by plants is divided into three processes, namely absorption by roots, translocation, and localization [8]. First, absorption by roots. The mechanism of metal absorption is through the formation of phytokhelatin substances. Fitokhelatin is a small peptide that is rich in cysteine amino acids that contain $\mathrm{S}$. Atom $\mathrm{S}$ in this cysteine which will bind heavy metals from the growing media. Fitokhelatin compounds found in plant roots function to bind the heavy metal elements $\mathrm{Pb}$ and $\mathrm{Cd}$ and carry them into cells. Fitokhelatin will form sulfide bonds at the $\mathrm{S}$ end of cysteine when it encounters $\mathrm{Pb}$ and $\mathrm{Cd}$ metals and then forms complex compounds so that $\mathrm{Pb}$ and $\mathrm{Cd}$ metals will be carried to plant tissues [9].

Second, metal translocation from roots to other plant parts. After the metal penetrates the root endodermis, the heavy metal follows the flow of transpiration through the transport network (xylem and phloem) to other plant parts. Third, metal localization in cells and tissues. The ability of plants to localize this metal becomes very important because it can describe the ability of plants to be able to tolerate and detoxify the heavy metal does not inhibit plant metabolism and prevent metal poisoning of cells. Echhornia crassipes detoxifies by accumulating heavy metals in vacuoles in their cell structures. The vacuole keeps the heavy metal from inhibiting metabolism so that the heavy metal will not affect the metabolic processes of plants.

Table 2 shows that the highest accumulation of heavy metals $\mathrm{Pb}$ and $\mathrm{Cd}$ is in the root organ. Metal accumulation is a localization effort carried out by plants, by collecting in one organ. In addition, the high accumulation of metals in the roots caused plants absorb nutrients and metals that are in the water through the roots. The root functions as an absorbent organ and supplies nutrients to other organs. Eichhornia crassipes has fiber roots, so that it has the ability to absorb heavy metals $\mathrm{Pb}$ and $\mathrm{Cd}$ more and more effectively. 


\subsection{Levels of Lead Metal $(\mathrm{Pb})$ and Cadmium (Cd) Accumulation in Eichhornia crassipes}

The level of accumulation of heavy metals $\mathrm{Pb}$ and $\mathrm{Cd}$ Eichhornia crassipes can be seen from the Bioconcentration Factor. Bioconcentration factor is a comparison between the concentration of metals that accumulate in aquatic organisms and the concentration of metals in the environment (its habitat) in this case river water. The ability of Eichhornia crassipes to accumulate metals in its body is shown as a bioconcentration factor value. This value is obtained by comparing the concentration of similar metals in Eichhornia crassipes samples with river water samples.

\section{1) Bioconcentration Factor (BCF) of $\mathrm{Pb}$ metal in Eichhornia crassipes}

The results of the calculation of the accumulation of heavy metals $\mathrm{Cd}$ on Eichhornia crassipes can be seen from the value of the bioconcentration factor in Figure 1 below.

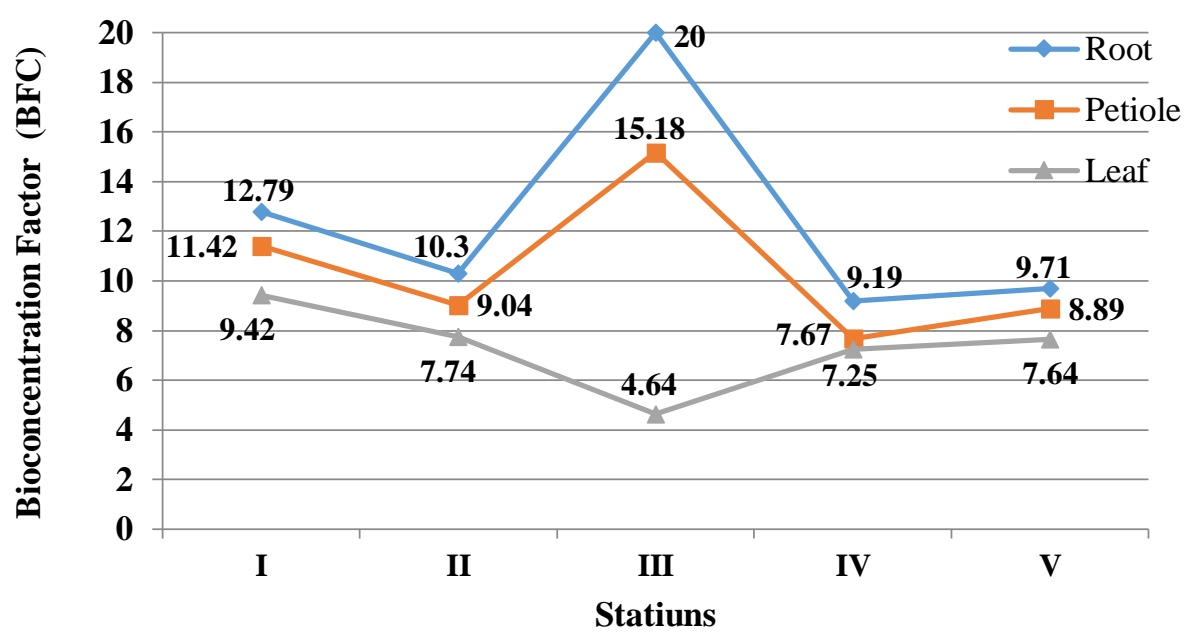

Figure 1. Bioconcentration Factor Value of Heavy Metal Pb atEichhornia crassipes

From Figure 1, the value of $\mathrm{Pb}$ heavy metal bioconcentration factor in the roots of Eichhornia crassipes ranged from 9.71 to 20.00 , the leaf stalks ranged from 7.67-15.18, and the leaves ranged from 4.64-9.42. These results indicate that the ability of Eichhornia crassipes to accumulate $\mathrm{Pb}$ heavy metals is higher in the root organ, as seen from the higher root bioconcentration factor value compared to the petiole and leaves.

Waldichuck [10], emphasized that the bioconcentration factor value category is BCF $<100=$ Low accumulation trait, BCF between 100-1000 = Medium accumulation trait, whereas BCF> $1000=$ High accumulation trait. Based on the value of the metal bioconcentration factor shown in Figure 1, it can be concluded that the level of accumulation of heavy metals $\mathrm{Pb}$ in Eichhornia crassipes belongs to the low accumulative category.

2) Bioconcentration Factor (BCF) of Cd Metal in Eichhornia crassipes 
The results of the calculation of the accumulation of heavy metals Cd on Eichhornia crassipes can be seen from the value of the bioconcentration factor in Figure 2 below.

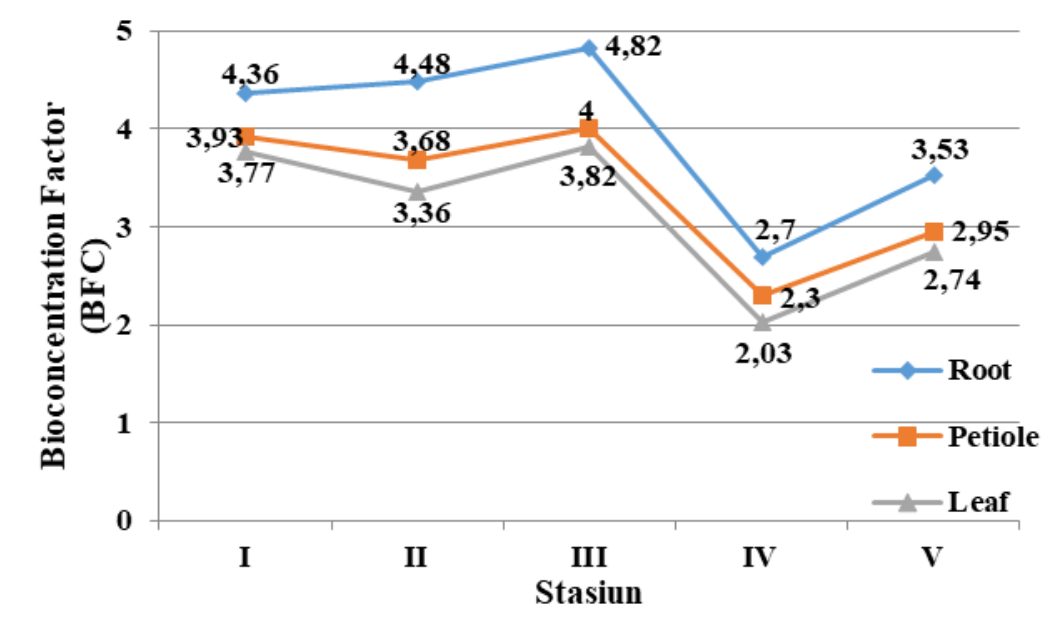

Figure 2. Bioconcentration Factor Value of Heavy Metal Cd in Eichhornia crassipes

From Figure 2, the bioconcentration factor value of heavy metal $\mathrm{Cd}$ at the roots of Eichhornia crassipes ranged from 2.70-4.82, the leaf stalks ranged from 2.30-4.00, and the leaves ranged from 2.03-3.82. These results indicate that the ability of Eichhornia crassipes in accumulating Cd heavy metals is higher in the root organ, as seen from the higher root bioconcentration factor value compared to the petiole and leaves. Based on the value of the metal bioconcentration factor shown in Figure 2, it can be concluded that the level of accumulation of heavy metals $\mathrm{Cd}$ in Eichhornia crassipion belongs to the low accumulative category.

\subsection{Bioconcentration Factor (BCF) of Cd Metal in Eichhornia crassipes}

The results of the calculation of the accumulation of heavy metals $\mathrm{Cd}$ on Eichhornia crassipes can be seen from the value of the bioconcentration factor in Figure 2 below.

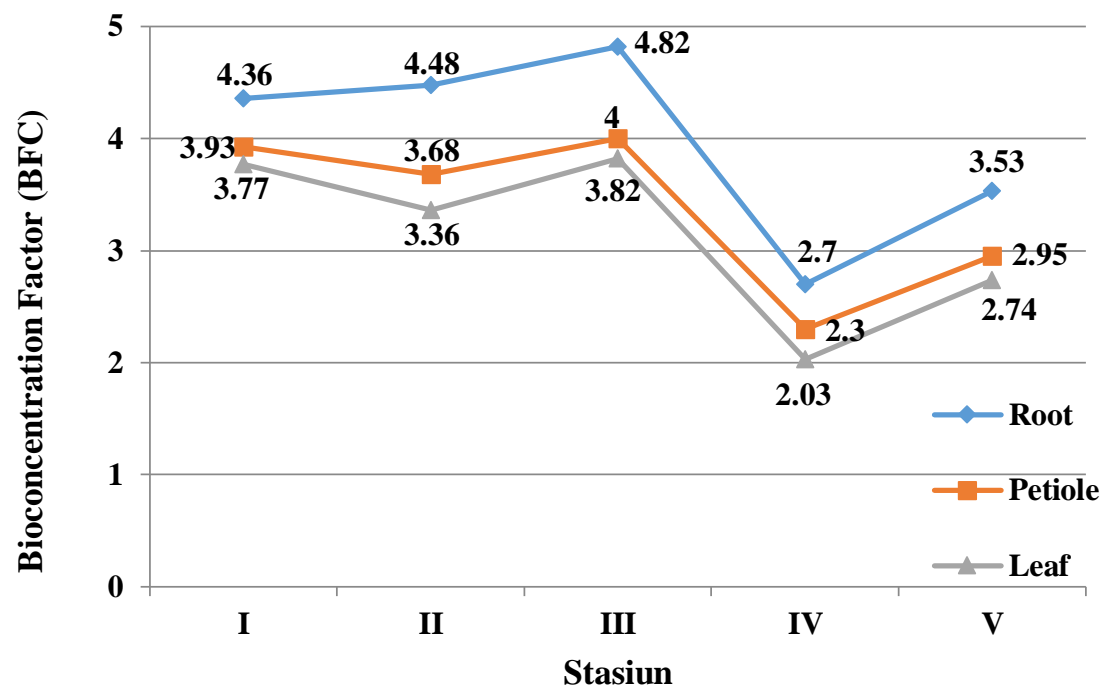

Figure 2. Bioconcentration Factor Value of Heavy Metal Cd in Eichhornia crassipes 
From Figure 2, the bioconcentration factor value of heavy metal $\mathrm{Cd}$ at the roots of Eichhornia crassipes ranged from 2.70-4.82, the leaf stalks ranged from 2.30-4.00, and the leaves ranged from 2.03-3.82. These results indicate that the ability of Eichhornia crassipes in accumulating Cd heavy metals is higher in the root organ, as seen from the higher root bioconcentration factor value compared to the petiole and leaves. Based on the value of the metal bioconcentration factor shown in Figure 2, it can be concluded that the level of accumulation of heavy metals Cd in Eichhornia crassipion belongs to the low accumulative category.

\subsection{Indragiri River Waters Quality}

Water quality parameters in this study are physico-chemical parameters which include: temperature, current speed, brightness, $\mathrm{pH}$, DO, substrate texture class, and organic substrate concentration (KOS). The results of water quality measurements for each station in the waters of the Indragiri River region of the Indragiri Hilir Regency can be seen in Table 3.

Table 3 Results of Measurement of Physical-Chemical Parameters in Sungi Indragiri waters

\begin{tabular}{clcccccc}
\hline \multirow{2}{*}{ No. } & \multirow{2}{*}{ Parameters } & $\begin{array}{c}\text { Quality standards } \\
(\text { normal })\end{array}$ & I & II & III & IV & V \\
\cline { 3 - 7 } 1 & Temperature $\left({ }^{\circ} \mathrm{C}\right)$ & - & 28.4 & 29.6 & 28.1 & 30.7 & 31 \\
\hline 2 & Current speed $(\mathrm{m} / \mathrm{s})$ & - & 0.37 & 0.27 & 0.29 & 0.22 & 0.17 \\
\hline 3 & Brightness $(\mathrm{m})$ & - & 0.23 & 0.13 & 0.27 & 0.15 & 0.09 \\
\hline 4 & $\mathrm{pH}$ & $6-9$ & 7.23 & 7.20 & 7.40 & 7.14 & 6.62 \\
\hline 5 & DO $(\mathrm{ppm})$ & $>4$ & 5.3 & 4.8 & 5.1 & 4.1 & 3.6 \\
\hline 6 & Texture class & - & Clay & Clay & Clay & Clay & Clay \\
\hline 7 & Substrate & & Sandy & Sandy & Dusty & Sandy & Dusty \\
\hline 8 & KOS $(\%)$ & 4.3 & 5.5 & 8.5 & 6.7 & 10.7 \\
\hline Note: & Quality Standards Based on PP No. 82 of 2001 concerning Management of Water Quality and Control of \\
& Water Pollution. & & & & &
\end{tabular}

Temperature is a very important water parameter because it can affect the physical-chemical nature of the waters and the physiology of aquatic organisms. The results of temperature measurements at each station did not show any striking variations. The temperature in the waters of the Indragiri River Indragiri Hilir Regency ranges between $28.1^{\circ} \mathrm{C}-31^{\circ} \mathrm{C}$. The optimal temperature range for organism's life is $25-32^{\circ} \mathrm{C}$. This range shows that the water temperature is good enough to support the survival of aquatic organisms.

Temperature affects the metabolic activity and organism development. In addition, temperature can also affect the concentration of heavy metals in waters. High temperatures will increase the formation of heavy metal ions and increase the concentration of heavy metals in the waters. It is seen that the highest $\mathrm{Pb}$ and $\mathrm{Cd}$ heavy metal values are at Station $\mathrm{V}$ with a temperature of $31^{\circ} \mathrm{C}$. Temperature will affect the metabolism rate of aquatic organisms. Increased metabolic rate will indirectly affect the concentration of heavy metals in the body of organisms originating from the environment. 
Flow is one aspect of water dynamics that plays a role in the distribution of biology and chemistry including pollutants in the form of heavy metals. From the measurement results, the current speed in the waters of the Indragiri River Indragiri Hilir Regency ranges between 0.17$0.37 \mathrm{~m} / \mathrm{s}$. The current velocity at each research station is an important mechanism to determine the spread of pollutants such as heavy metals. Hutagalung [11] states that the presence of heavy metals in waters is influenced by currents and waves, the flow of waters can cause metals dissolved in water to spread in all directions.

Brightness is a measure to determine the power of penetration of sunlight into the water. The higher the brightness, the deeper the power of sunlight penetration into the waters. The measurement results show the brightness in the waters of the Indragiri River Indragiri Hilir Regency ranges between 0.09-0.27 m. The highest brightness is found at Station III and the lowest brightness is found at Station V. The low brightness value is due to the presence of high dissolved and suspended substances in waters originating from activities around the research station.

The brightness value in the waters of the Indragiri River, Indragiri Hilir Regency is classified as low, because it is marked by river water that looks turbid and brownish in color. Brightness is greatly influenced by environmental factors. The level of brightness can indicate the presence of heavy metals in the waters. The relationship of brightness with the concentration of heavy metals is inversely proportional, where the lower the level of brightness of the waters, the concentration of heavy metals in water will be higher. This is because heavy metals bind with other particles so that it can block the process of penetration of sunlight entering the liquid.

$\mathrm{pH}$ is very important as a parameter of water quality because $\mathrm{pH}$ controls the type and rate of reaction speed in water. In addition, $\mathrm{pH}$ functions as a limiting factor because each organism has a tolerance of maximum and minimum $\mathrm{pH}$ values. The results of the measurement of the $\mathrm{pH}$ value at each research station did not show a high enough difference, ranging between around 6.62-7.40. The $\mathrm{pH}$ value at each research station is still relatively good and does not exceed the PP No.82 2001 quality standard, which ranges from 6-9. The $\mathrm{pH}$ range in the waters of the Indragiri River Indragiri Hilir Regency still supports the survival of aquatic organisms.

The $\mathrm{pH}$ value is very influential on the presence of heavy metals in the waters. The solubility of heavy metals will be higher at low $\mathrm{pH}$, causing the concentration of heavy metals in river water to be large. At Station III is the highest $\mathrm{pH}$ value of 7.40 but the lowest concentration of heavy metals $\mathrm{Pb}$ and $\mathrm{Cd}$ in river water. Vice versa at Station $\mathrm{V}$ is the lowest $\mathrm{pH}$ value of 6.62 while the highest concentration of heavy metals $\mathrm{Pb}$ and $\mathrm{Cd}$ in river water. This shows that the lower the $\mathrm{pH}$ value, the higher the concentration value of heavy metals. 
DO is the level of dissolved oxygen in water. DO in the waters of the Indragiri River Indragiri Hilir Regency ranges between 3.6-5.3 ppm. The highest dissolved oxygen level is at Station I and the lowest dissolved oxygen concentration is at Station V. Dissolved oxygen levels in the Indragiri River Indragiri Hilir Regency still support the life of aquatic organisms, in accordance with the decision of PP No.82 of 2001 that the levels of dissolved oxygen to support the life of organisms aquatic is $\mathrm{p} 4 \mathrm{ppm}$, but this does not apply to Station $\mathrm{V}$ due to dissolved oxygen levels below the established quality standards. The low oxygen content at Station V indicates the amount of waste found at that location. Changes in the level of dissolved oxygen can have a direct effect that results in the death of organisms being recognized

\section{Conclusion}

Based on the results of research that has been done, it can be concluded that the concentration of heavy metals $\mathrm{Pb}$ and $\mathrm{Cd}$ in the waters of the Indragiri River Indragiri Hilir Regency shows different values. The concentration of heavy metals $\mathrm{Pb}$ and $\mathrm{Cd}$ in river water tends to be lower than the concentrations of heavy metals $\mathrm{Pb}$ and $\mathrm{Cd}$ in Eichhornia crassipes and sediments. The concentration of $\mathrm{Pb}$ and $\mathrm{Cd}$ heavy metals in river water has passed the specified quality standard value, while the concentration of $\mathrm{Pb}$ and $\mathrm{Cd}$ heavy metals in sediments has not exceeded the determined quality standard value.

\section{REFERENCES}

[1] Pemerintah Kabupaten Indragiri Hilir. Kondisi Umum Kabupaten Indragiri Hilir. (Online). http://www.inhilkab.go.id/index.php/pages/kondisi-umum (Diakses Tanggal 20 Maret 2016). 2010.

[2] Nola Oktaria, T. Abu Hanifah, dan Sofia Anita. Analisis Kandungan Logam Merkuri, Kadmium, Timbal, dan Sianida pada Aliran Sungai Indragiri, 2015.

[3] Zhou, Q., Zhang, J., Fu, J., Shi, J., \& Jiang, G. Biomonitoring: an appealing tool for assessment of metal pollution in the aquatic ecosystem. Review. Analytica Chimica Acta. 606:135-150. 2008.

[4] Suwondo, Yuslim Fauziah, Syafrianti, dan Wariyanti. Akumulasi Logam Cupprum $(\mathrm{Cu})$ dan Zincum (Zn) di Perairan Sungai Siak dengan Menggunakan Bioakumulator Eceng Gondok (Eichhornia crassipes). Jurnal Biogenesis. 1(2):51-56. 2005.

[5] Darmono. Logam dalam Sistim Biologi Mahluk Hidup. UI-Press. Jakarta. 1995.

[6] Safitri, N. A., Rifardi, dan R. Hamidi. Konsentrasi Logam Berat Cd dan Pb pada Sedimen Permukaan Perairan Teluk Bayur Provinsi Sumatera Barat Indonesia. Jurnal Perikanan dan Kelautan. 2(3): 80-86. 2009.

[7] USEPA. The Incidence and Severity of Sediment Contamination in Surface Waters of United States, National Sediment Quality Survey: 2nd Edition. EPA-823-R-04-2007. US Enviromental Protection Agency. Washington D.C. 2004.

[8] Priyanto, B. dan J. Prayitno. Fitoremediasi sebagai Sebuah Teknologi Pemulihan Pencemaran Khususnya Logam Berat. http://tll.bppt.tripod.com/sublab/lflora1.htm. (Diakses Tanggal 25 September 2016). 2004.

[9] Salisbury, B.F. dan C.W., Ross. Fisiologi Tumbuhan Jilid I. ITB. Bandung .1995

[10] Fitri F. Kandungan Logam Berat Timbal $(\mathrm{Pb})$ pada Geloina sp. sebagai Bioindikator Kualitas Perairan di Laut Dumai. Skripsi tidak dipublikasikan. Fakultas Keguruan dan Ilmu Pendidikan. Universitas Riau. Pekanbaru. 2012.

[11] Hutagalung. Logam Berat dalam Lingkungan Laut. Pawarta Oseana. Jakarta. 1994. 